\title{
Identification of Subsurface Structures of Geothermal Potential Area in East of Mount Lawu Using The Gravity Method
}

\author{
Sorja Koesuma*, Mela Budiani Septianingsih, and Budi Legowo \\ Department of Physics, Faculty of Mathematics and Natural Science, Universitas Sebelas Maret, Surakarta \\ *sorja@staff.uns.ac.id
}

\begin{abstract}
Information about the eastern side subsurface stones of Mount Lawu regarding geothermal potential is limited. This research was conducted to provide information regarding geothermal potential in those area by using the gravity method. We did a 18 sites of gravity surveys in eastern flank of Mount Lawu where located in Magetan regency, Ngawi regency and Sragen regency, East Java. The principle of this method is to measure the earth's gravity field, then the value of gravity is corrected by some gravity corrections, i.e. height, tide, drift, normal gravity, free-air, Bouguer and terrain corrections. The Complete Bouguer Anomaly (CBA) shows the formation that related to the rock formation in the subsurface of Mount Lawu. Based on CBA modelling we found that in the eastern flank of Mount Lawu contains of tuff and breccia of volcanic rocks, breccia Jabolarangan and tuff Jabolarangan, lava andesite, igneous rock (pumice), and sedimentary rocks in the form of sandstone and clay. We found a fault structure on six tracks of a research area. Otherwise, we estimated that there is a geothermal potential on the southeast side of the research area
\end{abstract}

Keyword: Mount Lawu, Gravity Method, Fault, Geothermal Potential

\section{INTRODUCTION}

One area that has geothermal potential in Indonesia that has not been fully developed by the government is Mount Lawu. Mount Lawu has a stratotype that still has an active volcanic activity which is characterized by a small crater that blows fumaroles and solfatara. The position of Mount Lawu is adjacent to the collision area of the Indo-Australian and Eurasian plates, so it is suspected that the geothermal system exists in the region ${ }^{[1]}$.

Information about the geothermal potential of the west and south sides of Mount Lawu is quite much, while on the east side of Mount Lawu it is still quite limited. This research was conducted on the east side of Mount Lawu including Magetan Regency, Ngawi Regency, and Sragen Regency, to provide information about the geothermal potential in the region. This research was conducted to determine the existence of geothermal potential in the area from subsurface geology obtained using the gravity method.

\section{Theory}

Gravity method is one method to identify the differences in the value of rock density below the ground surface laterally and vertically ${ }^{[2]}$. The difference in the value of underground layer density and hot fluid activity in a geothermal reservoir results in variations in the density values of rocks so that the measured gravitational field values also vary. The variation in the gravitational field value is called the gravitational field anomaly. Gravity anomalies obtained can be used to determine the subsurface geological structure ${ }^{[3]}$. 


\section{a. Newton's Gravity Law}

It is the force between two particles having mass $m_{0}$ and $m$ directly proportional to the mass of the two particles and inversely proportional to the two distances between the centers of mass ${ }^{[4]}$ :

$$
F=\gamma\left(\frac{m_{0} m}{r^{2}}\right) \hat{r}
$$

Where $\mathrm{F}$ is the force acting on $m, \hat{r}$ is the direction of the vector from $m$ to $m_{0}, r$ is the distance between $m$ and $m_{0}$, and $\gamma$ is the gravitational constant. The value of $\gamma$ in SI is 6.672 $x 10^{-11} \mathrm{Nm}^{2} / \mathrm{kg}^{2}$, in units of cgs $6.672 \times 10^{-8}$ dyne $\mathrm{cm}^{2} / \mathrm{gr}^{2}{ }^{[4]}$.

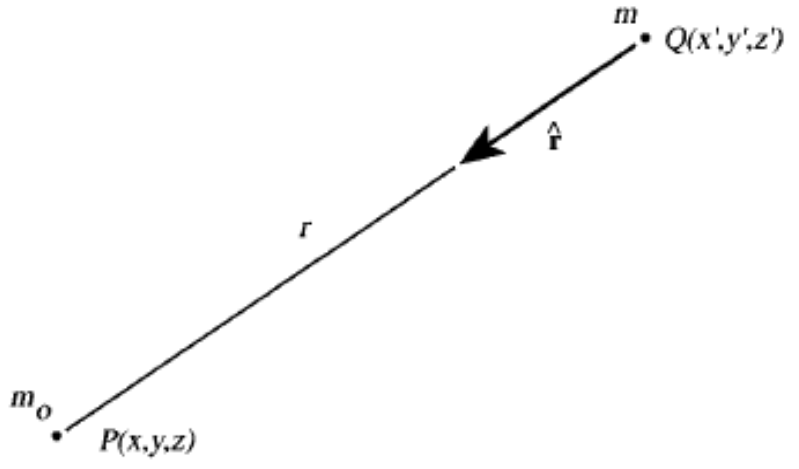

Figure 1. Mass $m$ and $m_{0}$ experience a gravitational force proportional to $m, m_{0}$, dan $r^{-2}$. The vector $\hat{r}$ is directed from the source of gravity to the point of observation (test mass $\left.m_{0}\right)^{[5]}$

\section{b. Gravitational Acceleration}

The gravitational field around the pulled mass is a pressing force (working) in a mass unit [6].

$$
g=-\gamma \frac{m}{r^{2}} \hat{r}
$$

The SI unit of gravitational acceleration is $\mathrm{m} / \mathrm{s}^{2}$, with other units, Gal is equivalent to 1 $\mathrm{cm} / \mathrm{s}^{2}$. The gravity value on the surface of the earth is $9.8 \mathrm{~m} / \mathrm{s}^{2}{ }^{[6]}$.

\section{c. Gravity Potential Mass Distribution}

The gravitational field is a conservative field, where the effort to move a mass depends only on the initial position and the final position and is the gradient of a scalar potential function $U(\bar{r})^{[4]}$.

$$
\begin{aligned}
& \nabla U(\bar{r})=-\frac{F(\bar{r})}{m^{2}}=-g(\bar{r}) \\
& U(\bar{r})=\int_{\infty}^{r} \nabla U(\bar{r}) \cdot d r=-\int_{\infty}^{r} g \cdot d r \\
& U(\bar{r})=-\gamma m \int_{\infty}^{r} \frac{d r}{r^{2}}=-\gamma \frac{m}{r}
\end{aligned}
$$

The geothermal system is a hydrothermal system that has existed since the earth was formed. The geothermal system includes the water system, the heating system in the earth, and the condition of the heated water system collected in one place. The requirements of geothermal systems are the availability of water, heating rocks, nest rocks, and cover rock ${ }^{[7]}$. 


\section{METHODS}

Gravity surveys were carried out at 18 locations on the east side of Mount Lawu. The observed data is then processed by applying several corrections, i.e. height correction, tide correction, drift correction. After this process we get Simple Bouguer Anomaly (SBA). further data processing in order to obtain Complete Bouguer Anomaly (CBA) required average density of survey area. The average density is obtained by using the Nettleton method. Figure 2 shows how to get the density average of survey area in Mount Lawu. The average density obtained at about $2.35 \mathrm{gr} / \mathrm{cm}^{3}$ which is the smallest correlation value. Based on geological information and average rock density, Mount Lawu is mostly composed of Andesite rocks.

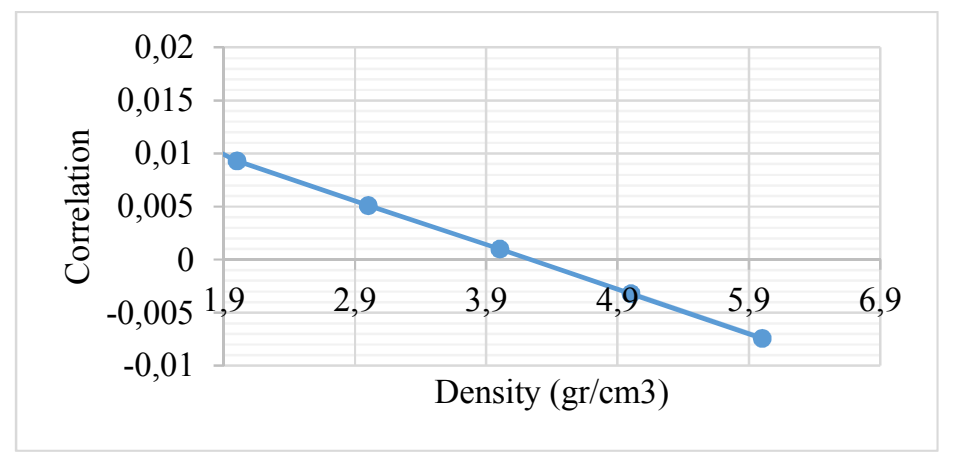

Figure 2. The relationship graph of density vs correlation using Nettleton method

For further process, we applied normal gravity correction, free-air correction, Bouguer correction, and terrain correction to SBA to get the Complete Bouguer Anomaly (CBA). After applying this corrections we get the Complete Bouguer Anomaly (CBA).

After obtained the CBA, we make a flat field reduction process, so that the CBA value is at the same elevation. Flat field reduction is done by the mass point equivalent method ${ }^{[8]}$. Where the distance between points is $2.600 \mathrm{~m}$, the equivalent depth of the mass point is $9.000 \mathrm{~m}$, and the height of the flat field is $2.352 \mathrm{~m}$ from the reference spheroid (ellipsoid). CBA maps that have reduced flat fields are used for input in spectrum analysis.

Data slicing on flat field reduced CBA maps is done by Fast Fourier Transform (FFT) calculation. From the $\operatorname{Ln}(A)$ the graph on wave number $(k)$, we can know the depth estimation of regional and residual anomalies used for forward modeling (2D), and the width of the window for separating anomalies.

The moving average method is used for the separation of regional and residual anomalies. The results of this separation are regional anomalies. The result of the reduction between reduced CBA flat fields and regional anomalies is a residual anomaly. Qualitative analysis is obtained from the residual anomaly graph with distance, the result of the residual slicing map. Quantitative analysis was obtained from the results of residual map trajectory modeling. 


\section{RESULTS AND DISCUSSIONS}

The flat-reduced CBA in the flat plane is shown in Figure 3.(a). Anomalies range from 68 $\mathrm{mGal}$ to $112 \mathrm{mGal}$. The anomalous value is still at a variation elevation. The reduced CBA describes the anomaly value in a flat plane at an altitude of 2,352 meter above the spheroid reference. Comparing to CBA map, it can be seen that the reduced CBA has some regions that have high anomalies. It happens because of topographic influences. The CBA value will encounter an increase or decrease depending on the initial elevation before the flat plane is reduced.

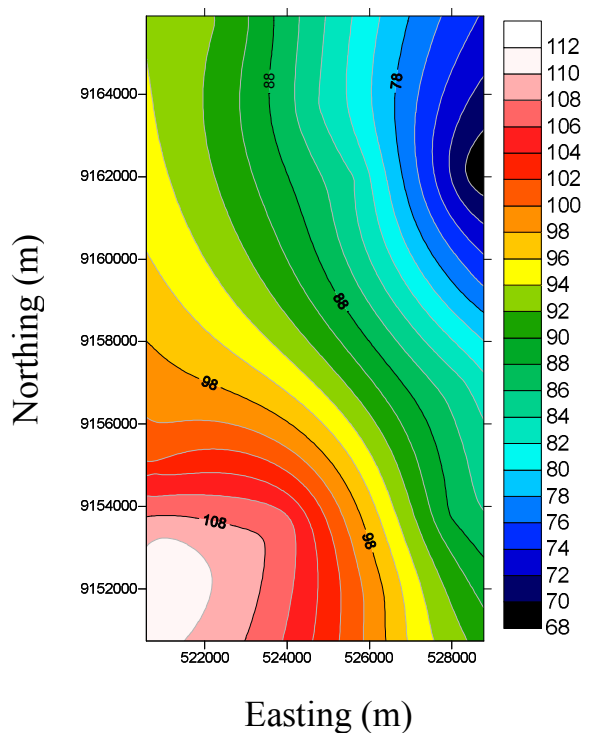

(a)

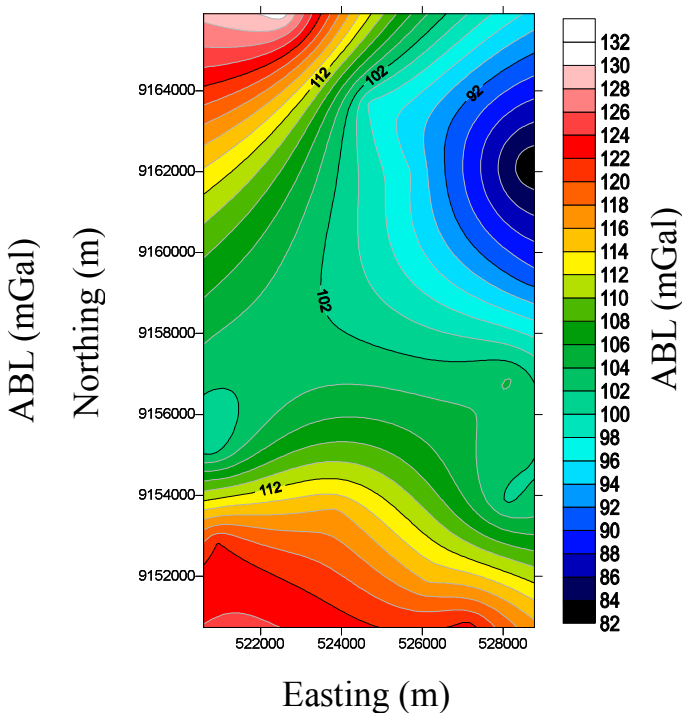

(b)

Figure 3. Maps of (a) CBA (b) Flat-reduced CBA

Table 1. Depth of anomaly at five slicing data track

\begin{tabular}{crcc}
\hline Number & Track & $\begin{array}{c}\text { Depth of regional } \\
\text { Anomaly }(\mathrm{m})\end{array}$ & $\begin{array}{c}\text { Depth of residual } \\
\text { Anomaly }(\mathrm{m})\end{array}$ \\
\hline 1. & A-A' & 6,678 & 325 \\
2. & B-B' & 6,987 & 765 \\
3. & C-C' & 4,557 & 233 \\
4. & D-D' & 6,862 & 294 \\
5. & E-E' & 9,706 & 339 \\
& Average & 6,958 & 391
\end{tabular}

Furthermore, we do spectral analysis for flat-reduced CBA data. This process is to determine the optimum regional and residual anomalies. Table 1 shows the results of all five slicing data track. We found, the average regional and residual anomalies are 6,958 meter and 391 meter, respectively. The average residual depth value will be used as the maximum depth when doing modeling. 


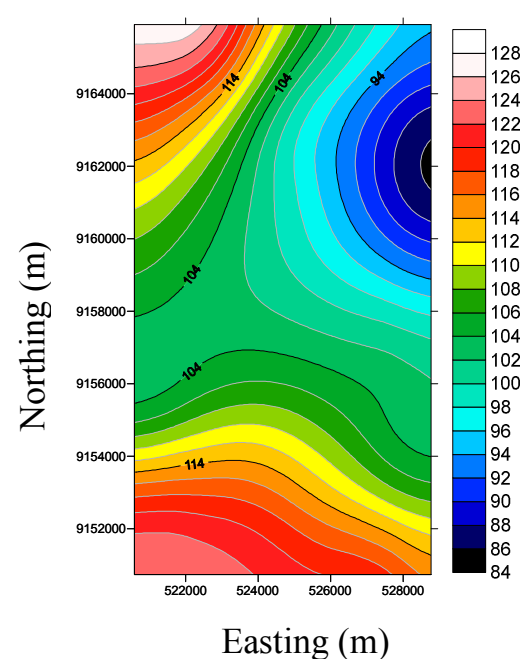

(a)

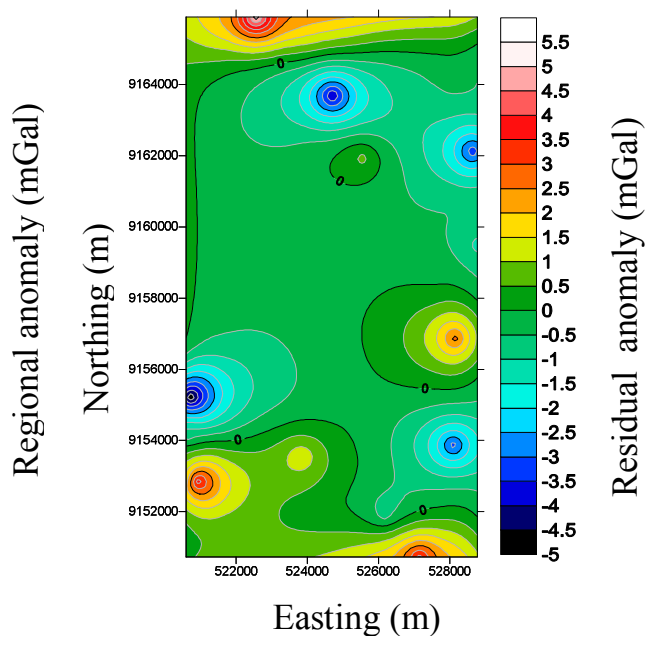

(b)

Figure 4. Maps anomaly (a) regional (b) residual after the moving average

From Figure 4. (a) regional anomalies are smoother than the reduced CBA plane map. It is because the moving average filter is a low pass filter, where the separation is carried out on anomalies that have a low frequency in the result that a regional anomaly map is produced which has a low-frequency characteristic. Regional anomalies are anomalies originating from the inside of the earth. The regional gravity anomaly is $84 \mathrm{mGal}$ to $128 \mathrm{mGal}$. Figure 4.(b) shows the map of residual anomalies with variations in anomalous values from $-5 \mathrm{mGal}$ to $5.5 \mathrm{mGal}$. There is a simpler color gradation, smaller and higher anomaly area. Whereas the green anomalies are more widely spread. This is because anomalies at shallow depths are reflected in shorter wavelengths and high frequencies. So that from the residual anomaly can be seen the geological structure in more detail.

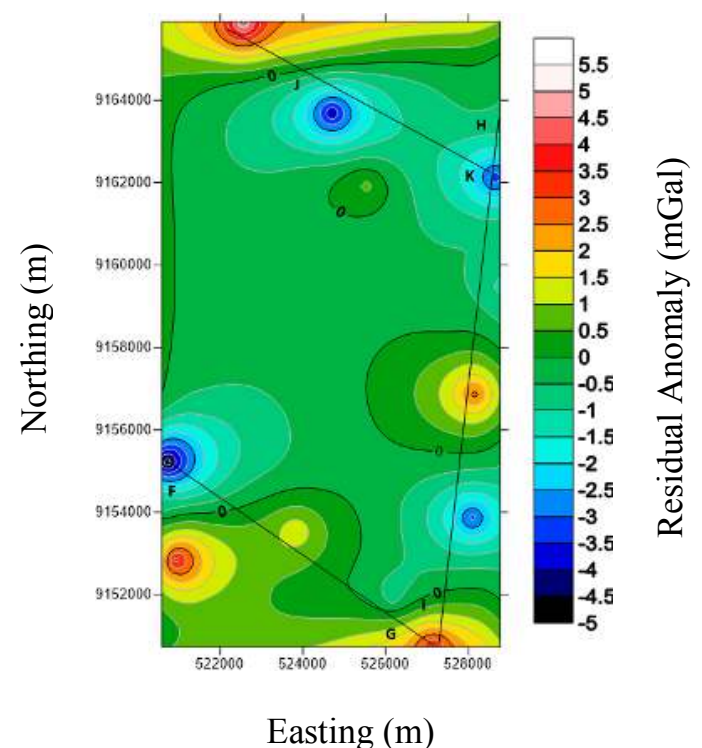

Figure 5. Modeling trajectories on the residual map 


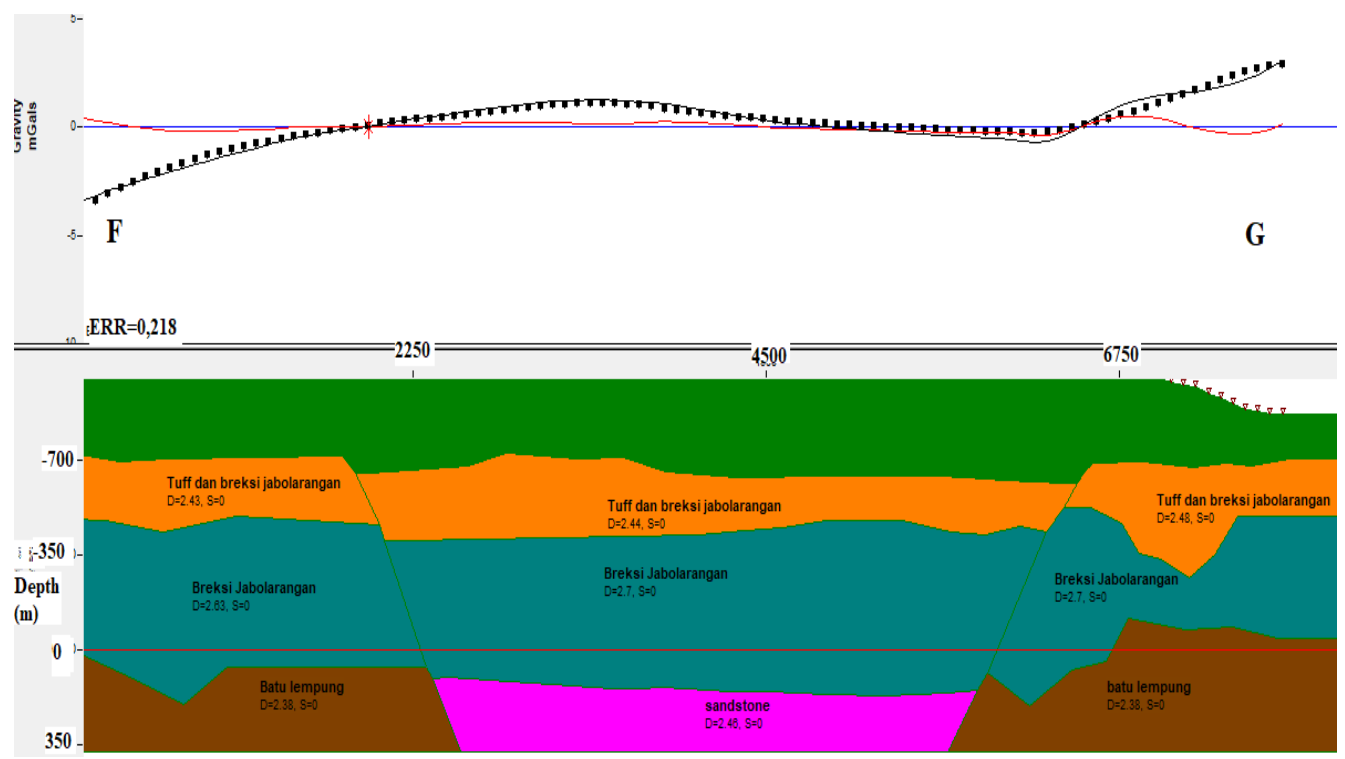

Figure 6. Subsurface modeling on F-G slices

Figure 6 shows the modelling of the F-G slice, there is one reverse fault and one normal fault. This modeling depth is $348 \mathrm{~m}$ from the bottom of the ellipsoid and 687 above the ellipsoid. The first layer of modeling with rock specific gravity of $2.43 \mathrm{gr} / \mathrm{cm}^{3}$ to $2.48 \mathrm{gr} / \mathrm{cm}^{3}$ is Tuff and Breccia rock, results from the eruption of Old Lawu Mountain or Jabolarangan. These rocks are included in the Lawu Volcano (Qvl) rock formation with andesite lava inserts. The formation (Qvl) is at an average depth of $452.85 \mathrm{~m}$ to $687 \mathrm{~m}$ above the ellipsoid. In the second layer with a rock density of $2.63 \mathrm{gr} / \mathrm{cm}^{3}$ to $2.7 \mathrm{gr} / \mathrm{cm}^{3}$, it is Breccia rock. These rocks are included in the Breccia Jabolarangan (Qvjb) rock formation with andesite lava inserts. The depth of Breccia rock (Qvjb) averages $90.55 \mathrm{~m}$ below the ellipsoid to $452.26 \mathrm{~m}$ above the ellipsoid. The third layer with an average depth of $90.55 \mathrm{~m}$ to $86.80 \mathrm{~m}$ below is a clay rock with a density of $2.38 \mathrm{gr} / \mathrm{cm}^{3}$, and sandstone (sandstone) with a density of 2.46 $\mathrm{gr} / \mathrm{cm}^{3}$. Clay and sandstone rocks are included in the Semilir formation (Tms). The value of trial and error on the F-G slice modification is 0.218 , the smaller the value of the trial error indicates that the structure modeling is made almost close to the actual rock structure. 


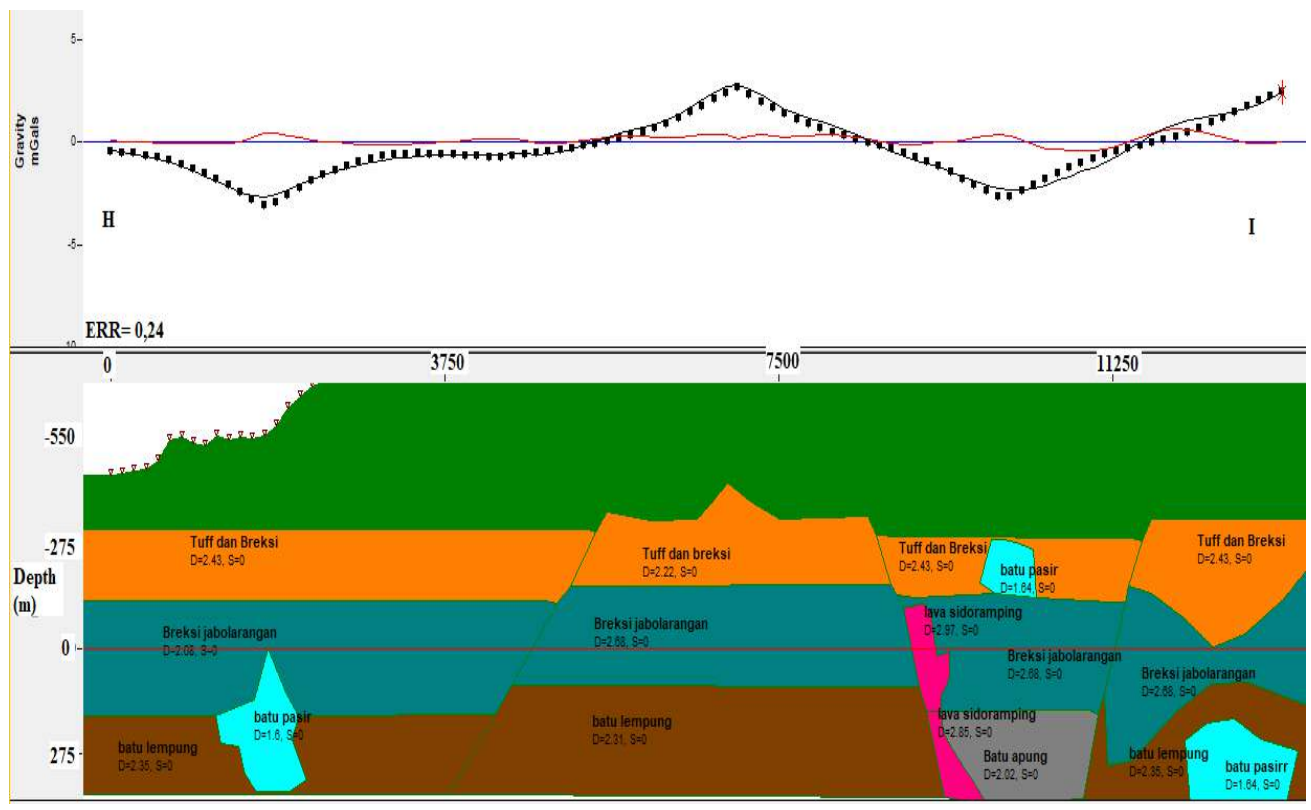

Figure 7. Subsurface modeling on H-I slices

Figure 7 shows the modelling of the H-I slice, there are three normal faults. There are rocks of the volcano $(\mathrm{Qvl})$, namely Tuff and Breccia with a density of $2.22 \mathrm{gr} / \mathrm{cm}^{3}$ and $2.43 \mathrm{gr} / \mathrm{cm}^{3}$. The depth of this formation is $336.29 \mathrm{~m}$ to $116.20 \mathrm{~m}$ above the ellipsoid. The second layer with a density of $2.68 \mathrm{gr} / \mathrm{cm}^{3}$ is composed of Breccia rocks including the Breccia Jabolarangan (Qvjb) formation with a depth of $116.20 \mathrm{~m}$ above the ellipsoid to $105.74 \mathrm{~m}$ below the ellipsoid. The third layer has clay rock with a specific gravity of $2.35 \mathrm{gr} / \mathrm{cm}^{3}$, the clay rock includes a Semilir formation (Tms) with a depth of $105.74 \mathrm{~m}$ to 385.27 below the ellipsoid. On this modeling trajectory, some sandstones are spread with a specific gravity of $1.64 \mathrm{gr} / \mathrm{cm}^{3}$. There are pumices with a specific gravity of $2.02 \mathrm{gr} / \mathrm{cm}^{3}$. The sandstone and pumice are Semilir formations (Tms). There are Sidoramping lava rocks located close to the hard type 2.85 to $2.87 \mathrm{gr} / \mathrm{cm}^{3}$. The trial and error on the H-I trajectory modeling are 0.225 .

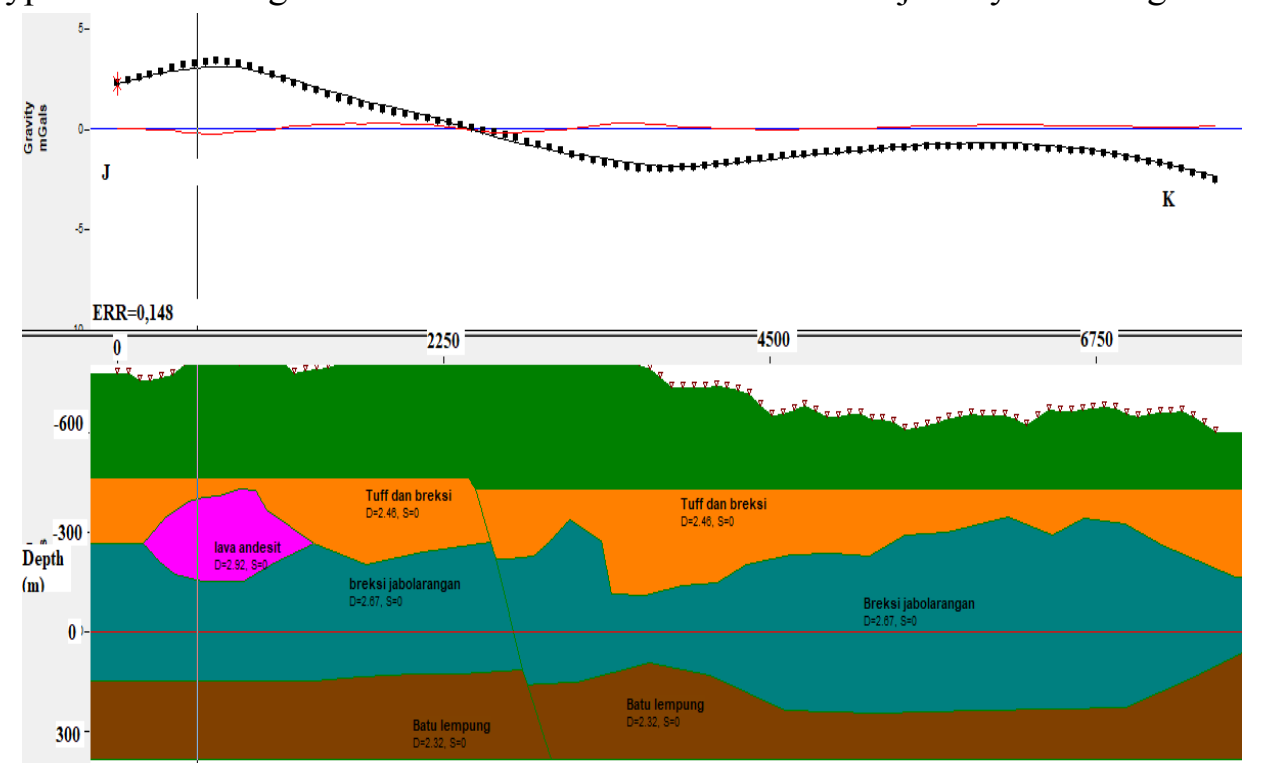

Figure 8. Subsurface modeling on H-I slice 
Figure 8 shows the modelling of the J-K trajectory, one normal fault was found. The first layer is Tuff and Breccia rock with a density of $2.46 \mathrm{gr} / \mathrm{cm}^{3}$ with an average depth of $233 \mathrm{~m}$ to $432 \mathrm{~m}$ above the ellipsoid. These rocks are included in the Volcanic (Qvl) formation. The second layer is Breccia Jabolarangan (Qvjb) rock with an average depth of $125.68 \mathrm{~m}$ below the ellipsoid to $243 \mathrm{~m}$ above the ellipsoid. There are Andesite Lava rocks between the first and second layers with a density of $2.92 \mathrm{gr} / \mathrm{cm}^{3}$. This lava comes from the eruption of young Mount Lawu. The third layer has claystone with a density of $2.32 \mathrm{gr} / \mathrm{cm}^{3}$ with a depth of $139.86 \mathrm{~m}$ to $37.35 \mathrm{~m}$ below the ellipsoid. The value of error in the J-K trajectory modeling is 0.148 .

From the subsurface modeling obtained from three trajectories, the geothermal potential that is assumed to be in the second trajectory area is the H-I path. Where in the area there are Andesite lava rocks that have a density of $2.85 \mathrm{gr} / \mathrm{cm}^{3}$ to $2.97 \mathrm{gr} / \mathrm{cm}^{3}$. Andesite Lava rocks are thought to be impermeable overburden that towers near the second fault on the H-I path. There is a pumices that has a low density of $2.02 \mathrm{gr} / \mathrm{cm}^{3}$ as a rock that has good permeability. The permeability of a rock is a measure of the ability of rocks to drain fluid and as a parameter in determining the velocity of fluid flow in porous rocks or fractured rocks. The third fault of the H-I trajectory modeling is the fluid outflow path. The fault is referred to as the place where meteoric water enters and then passes through the permeable rock. The meteoric water that enters, heated by hot rocks that are underneath which causes the temperature to be high so that the water can rise in resulting the water coming from the surface has a lighter density which will dropdown. In the fault, there is a process of transferring heat by convection to the fluid. The hot fluid that flows on the third fault, resulting in heat transfer by conduction in the surrounding rock so that the density of the rock becomes small, because high temperatures affect the formation of pores in rocks.

\section{CONCLUSIONS}

We found that, there are five normal and one reverse faults. The reverse and one normal fault are on the F-G trajectory, three normal faults on the H-I trajectory, and one fault found on the J-K trajectory. The geological structure of the compilers of Mount Lawu, namely Tuff and Breccia (Qvl), Jabolarangan Breccia (Qvjb), Igneous Rock (Pumice), and Sedimentary Rocks in the form of Clay and Sandstone are Semilir (Tms) formations and Andesite lava rocks.

It is assumed that there is geothermal potential in the southeast of the study area on the H-I trajectory. The geothermal potential is based on obtained results of fault modeling and geological structure.

\section{REFERENCES}

1 Amalisana, B., Pin, T., \& Saraswati, R. 2017. Penentuan potensi panas bumi menggunakan Landsat 8 dan hubungannya dengan kondisi geologi Gunung Lawu. 8 th Industrial Research Workshop and National Seminar, Politeknik Negeri Bandung.

2 Musset, A. E., \& Khan, M. A. 2000. Looking Into The earth. New York: Cambridge University Press.

3 Reswara, A., \& Sehah. 2014. Pendugaan lapisan reservoir panas bumi di kawasan gunungapi Slamet dengan memanfaatkan data anomali medan gravitasi citra satelit. Jurnal Berkala Fisika, 17, 45-54.

4 Telford, W. M., Geldart, L. P., \& Sheriff, R. E. 1990. Applied geophysics second edition. New York: Press Syndicate of University of Cambridge. 
5 Blakely, R. J. 1996. Potential theory in gravity and magnetic applications. New York: Cambridge University Press.

6 Lowrie, W. 2007. Fundamentals of geophysics. New York: Cambridge University Press.

7 Alzwar, M. 1998. Pengantar ilmu gunungapi. Bandung: Penerbit Nova.

8 Dampney, C. N. G. 1969. The equivalent source technique. Journal Geophysics, Vol. 34,1 . 